\title{
ПОЉАДИЈА: ЖИВОТ У ПОГРАНИЧЈУ
}

\begin{abstract}
Апстракт: На основу четири транскрипта разговора вођених у Ланговету/Луговету у Пољадији (Румунија) 2019. прилог прати сећање на време затварања државне границе између Југославије и Румуније 1947. године из перспективе детета. Истовремено, кроз празновање првог петка после Ускрса становници Ланговета/Луговета чувају сећање на страдање деце у насељу у неком историјски већ избледелом периоду, али је овај празник данас постао један од важних етничких симбола у календару Срба у Румунији. Из антрополошко-лингвистичког угла показује се метапрагматичка свест о добром знању српског језика кроз термине усвојене у периоду социјализма, као и румунску административну лексику везану за границу и прелазак границе ('пасош', 'царина', 'граница').
\end{abstract}

Кључне речи: пограничје, усмена историја, биографске приче, Срби у Румунији, социјализам, Ланговет/Луговет.

Прилог је настао на основу грађе прикупљене тимским теренским истраживањима Срба у насељима Соколовац (rum. Socol), Златица (rum. Zlatița) и Ланговет/Луговет (rum. Câmpia) ${ }^{3}$ обављеним почетком јуна 2019. у организацији Центра за научно истраживање Срба у Румунији, при Савезу Срба у Румунији. ${ }^{4}$

\footnotetext{
${ }^{1}$ biljana.sikimic@bi.sanu.ac.rs

2 Прилог је резултат рада у оквиру пројекта Истраживање културе и историје Срба y Румунији, који се реализује уз помоћ Центра за научна истраживања и културу Срба у Румунији при Савезу Срба у Румунији.
}

${ }^{3}$ Из истраживања је било изостављено пољадијско село Лесковица, са уверењем да тамо више нико не говори српски. Према подацима из средине 20. века, у питању је врло сиромашно сточарско насеље, најсиромашније херско село у Румунији. Сматрају се Србима, али ни у то време многи нису говорили српски. Ипак, Лесковчани су певали српски и играли српске игре. Румунски језик је био уведен у школу 1923, а имали и српску школу. „Сиромашнији се издају за Румуне. Према обавештењима са друге стране, ипак, има доста њих у селу који знају српски. У селима на нашој страни често смо сретали лица родом из Лесковице која су знала само српски” (Букуров, Филиповић 1958: 52). Према актуелним подацима из темишварске „Наше речи”, старији људи у Лесковици још увек знају српски, али је служба у локалној цркви на румунском језику: „Краћом беседом верницима се обратио месни парох, али на румунском. (...) „Ми, ови стари, говоримо српски. Сви знају српски, ал' знате како..." - рекао нам је слежући помирљиво раменима Милан Стојановић.” (Деспотовић, 2019: 20). УП. и монографију посвећену овом насељу: Radan, 2003.

${ }^{4}$ У тиму су биле Смиљана Ђорђевић Белић, Светлана Ћирковић и Биљана Сикимић, 
Ова три насеља, захваљујући свом географском положају, била су у режиму малограничног промета од 1970. године, који је њиховим становницима давао право на одређени број путовања годишње у трајању од по шест дана за свако путовање у пограничној зони у Југославији. Граница и живот у пограничју јављали су се спонтано у разговорима на сасвим различите теме, било да је реч о календарским празницима у којима учествују или су некада учествовали Срби са обе стране границе (као што је то данас заједничка прослава празника Богојављења на реци Нери), ${ }^{5}$ заједничка култна места (манастири Златица и Кусић), али и у наративима усмене историје и биографских прича. Сећања на некадашњи живот у пограничју везана су за различите аспекте живота у периоду пре и током Другог светског рата, за период ,затварања границе”, затим период Чаушескуовог социјализма, за период „санкција” у Југославији све до данас. У питању је широк дијапазон тема из свакодневног живота, сећања на некадашња средства комуникације (воз до Базјаша до Беле Цркве, мост на Нери), сећање на илегалне преласке границе истовремено са сећањем на дозвољену малограничну трговину. Пољадијци су имали право на „мали пасош” захваљујући коме се у Пољадији живело боље него у унутрашњости Румуније. Посебно место у разговорима заузимало је обавезно помињање породичних веза са људима у насељима са друге стране границе - све до града Београда, као и до данас нерешеног питања двовласничких имања, односно имовине која је успостављањем границе остала са друге стране реке Нере, у Југославији.

Чини се да су слична интердисциплинарна тимска теренска истраживања Банатских Хера (којима припадају српска села у Пољадији) ${ }^{6}$ била обављена средином 20. века, а резултирала су објављивањем зборника радова 1958. Према у монографији објављеним подацима, та теренска истраживања Банатских Хера била су започета маја 1950, настављена 1953. године, да би зборник био објављен тек 1958. Дијалектолошки опис говора Банат-

истраживање је трајало четири радна дана: по један дан у Златици и Соколовцу и два дана у Ланговету. Осим тима Балканолошког института САНУ на терену Пољадије током лета 2019. У оквиру истог пројекта радили су још етнолози и лингвисти из Србије.

${ }^{5}$ Нешто северније, граница између Србије и Румуније иде реком Караш која једним делом раздваја румунска насеља: три насеља са српске стране (Куштиљ, Јабланка и Сочица) и једно са румунске (Врањ, рум. Vrani) имају крст на који се заједнички излази на празник Духови (рум. Rusalii). Крст има назив бели крст (рум. ruga albă) или крст на четири стуба (рум. crucea cu patru stâlpi), на њему се благосиљају усеви сва четири сеоска атара, данас подељена државним границама (детаљније в. Đurić-Milovanović, 2007).

${ }^{6}$ Етнолози нису тачно утврдили границе територије становништва које се зове Херама. Несумњиво су то села: Лесковица, Луговет/Ланговет, Златица и Соколовац/Сакаловац на левој страни реке Нере/Нераља, а на десној страни су Калуђерово, Кручица/Крушчица, Кусић, Црвена Црква, Врачев Гај и Паланка. Граница Хера у Румунији је јасно одређена и одвојена од Клисураца. Западна граница није тако чврста, некада се и насеља Јасеново и Дупљаја сматрају за херска (другачије у: Филиповић 1958б: 14), а у близини Врачев Гаја се налази и српско село Кајтасово. 
ски Хера (Ивић, 1958) заснива се на теренским истраживањима села Крушчица (обављеним 1948) и на дужем разговору са једном становницом села Врачев Гај уз консултацију теренских бележака етнолога Миленка Филиповића. ${ }^{7}$ Значајна су била и теренска истраживања темишварског музиколога Саве Илића (1935-1989) који је своју етномузиколошку збирку сакупљао седамдесетих година 20. века у клисурским насељима и Соколовцу (Илић, 2006). Још један важан извор представља аутобиографија Дејана Адама и његово сећање на детињство проведено у Златици почетком 20. века, на време балканских ратова и Првог светског рата (када Златица још није била у „пограничју”), до разграничења је дошло августа 1919: „И због те границе имао сам касније много потешкоћа у даљем школовању" (Адам, 1992: 94). Постоји и низ локалних монографија које се делом или у целини односе на српска насеља у Пољадији (Станојловић, 1938; Лупуловић 2003; Лупуловић 2012; Лупуловић, Гароју, 2008; Лупуловић, Крстић 1999; Лупуловић, Крстић 2001; Лупуловић, Томашевић, 2007; Крстић, 2015 и др).

Да би се компликоване промене правног статуса југословенско - румунске границе на реци Нери и њихов одраз на живот становника Пољадије - а у овом прилогу реч је само о једној, румунској страни, и то само о једном пољадијском насељу Луговету/Ланговету, у наставку је дат хронолошки преглед најважнијих историјских дешавања која су могла утицати на живот становника Пољадије. ${ }^{8}$

За комуникацију Пољадијских насеља са централном Европом најважнија је била изградња железничке пруге Оравица - Јасеново - Бела Црква - Базјаш (1856), која је две године касније (1858) од Беле Цркве преко Јасенова продужена за Вршац и даље за Темишвар, Сегедин, Будимпешту и Беч. Масовно досељавање у град Белу Цркву почиње после изградње пруге, али после успостављања границе Југославије и Румуније (1919) значај Беле Цркве опада када је граница Краљевине СХС и Румуније успостављена на Париској мировној конференцији. У међуратном периоду власницима пољопривредних имања са друге стране граница могли су да прелазе границу захваљујући сталној легитимацији (буквар), а од 1937. погранично становништво је могло да улази у другу земљу до дибине од десет километара и да слободно обавља трговину (Станојловић 1938: 27-28). Током Другог светског рата српска мањина је помагала народноослобдилачки покрет у Југославији, током 1944. велики број мањинаца управо из Пољадије и Клисуре се активно укључује у ЈНА, непосредно после рата око 1300 омладинаца учествује на радним акцијама у Југославији. После исељавања Немаца,

\footnotetext{
${ }^{7}$ У питању су обимне теренске белешке из Крушчице, Кусића, Врачев Гаја, Калуђерова, Црвене Цркве, Беле Цркве и Банатске Паланке прикупљене током 1950. и 1953.

8 Подаци у овом историјском прегледу преузети су из већ наведених локалних и етнолошких монографија, као и из истраживања историчара Миодрага Милина са сарадницима (Милин, Милин, 2004; 2009; Милин, Милин, Михајлов, 2011; Milin, Milin, 2014; 2017) и историчара Владимира Цветковића (Цветковић, 2011; Cvetković, 2013) о периоду после Другог светског рата.
} 
у Белу Цркву досељавају се колонисти из разних крајева Србије, али и око сто породица из Пољадије (Луговет, Златица и Соколовац) и Клисуре као породице добровољца учесника НОБ-а (Филиповић, 1958а: 371), Париски мировни уговор, закључен 10. фебруара 1947. потврђује већ постојеће границе између Југославије и Румуније. Стање на државној граници се драматично погоршава у периоду Информбироа, када румунске власти бележе „илегалну југословенску активност” у 80 села дуж југословенско-румунске границе у лето 1949. Истовремено, Румунија са Југославијом прекида друмски, железнички и речни, па чак и поштански саобраћај (на прузи Зрењанин - Жомбољ) и затвара све граничне прелазе. До марта 1955. забележен је 1761 погранични инцидент, а уз саму граничну линију постављени су снажни звучници који су се могли чути километар унутар југословенске територије. До обнове дипломатских односа Југославије и Румуније долази новембра 1954. а током 1955. решавана су најосетљивија питања: положај српске националне мањине, југословенских грађана у затворима, двовласничка имања и малогранични промет. Односи две земље коначно се успостављају после Титове посете Румунији јуна 1956. када почињу и први договори о будућој заједничкој хидроцентрали у Ђердапу.

Значајну временску границу у усменој историји пољадијских насеља представља затварање државне границе између Југославије и Румуније после Париског мировног уговора 1947. године. ${ }^{9}$ За људе у жупанији Тимиш-Торонтал, година 1947. није била значајна само због дефинитивног успостављања границе са Југославијом већ и због великих политичких промена у Румунији: промена према опозицији, монетарне реформе, одлука о национализацији индустрије и колективизације пољопривреде: то је година у којој Румунска комунистичка партија постаје апсолутни владар (Rămneanțu, 2004-2005).

Одломци из разговора који следе вођени су у Ланговету/Луговету са три саговорнице (једна је 1934. годиште, а две 1941) и једним саговорником (1943); једна саговорница је рођена у Соколовцу а удата у Ланговету, зато се њена сећања на детињство односе на Соколовац. ${ }^{10}$

\section{1. Колективно сећање: Крст деце}

Према етнологу Миленку Филиповићу (Филиповић,1958: 295-295), у пољадијским насељима постоје три врсте општих слава које слави цело

\footnotetext{
9 Политичку историју тог периода у Пољадији и Клисури в. у: Milin, Milin, 2014.

10 У прилогу су коришћени снимци: Langovet 1 BS.1.06.2019; Langovet2SC_1.6.2019, Langovet1sdj; Langovet4sdj, које су снимили истраживачи Биљана Сикимић (БС), Светлана Ћирковић (CЋ) и Смиљана Ђорђевић Белић (CЂ). Сви снимци су архивирани у Дигиталном архиву Балканолошког института САНУ у Београду и Савезу Срба у Румунији. Транскрипцију одабраних делова разговора са темом усмене историје урадила је Биљана Сикимић (транскрибовано је око 14000 речи што је свакако довољно за основне дијалектолошке и прагмалингвистичке закључке).
} 
село: црквене (оног свеца коме је иначе посвећена црква у селу), затим заветине (славе се током пролећа или лета за добар род летине), док би треће биле - марвене (за здравље стоке) и дечије славе (за здравље деце), које се такође сматрају за заветине, али су настале у новије време и конкретан повод због кога су уведене је познат. Филиповић као дечију (дечиъу) славу помиње само прославу Крстовдана у Златици, ${ }^{11}$ али не и прослављање првог петка после Ускрса у Ланговету.

Као и друга пољадијска насеља, и Луговет/Ланговет се налази на самој обали граничне реке Нере/Нераља, наспрам Беле Цркве (село Златица је наспрам села Кусића, а Соколовац наспрам Врачев Гаја). Његови становници га зову Ланговет, а они сами су - Ланговци, службени српски назив је Луговет (Крстић, 2015: 8-9). Према попису из 2011. у селу је живело 286 Срба (54,6\%). ${ }^{12}$ У Ланговету постоји српско забавиште у коме је 2014. било седморо деце, али нема наставе српског језика у основној школи (Степанов/ Степанов, 2014: 78, 83).

У Луговету/Ланговету Савез Срба у Румунији првог петка после Ускрса (Источни петак) традиционално организује празник Kpсm деце, за који се користе и темини Крст деце Луговета и Дечја слава. ${ }^{13}$ Савремена прослава подразумева заједничку литију мештана до крста који је 2009. године подигла породица Бушатовић, где након молитве и освећења кољива деца певају духовне песме и рецитују. Данас на ту прославу долазе гости из Србије, из Крушчице, будући да постоји сарадња школа из Крушчице и Луговета.

\footnotetext{
${ }_{11}$ Дечија слава у Златици уведена је 1877. или 1878. године када је „био велики помор деце”, тада је обновљен и стари крст из 1818. „После службе у цркви са литијом би изашли до тог крста. Деца би прилазила крсту и целивала га. После подне би било дечје весеље у порти. Неки родитељи су тада деци давали поклоне (играчке). Одрасли би се веселили уз пиће, колаче и печење. Богатији су то доносили сами и гледало се ко ће донети лепше колаче и више вина, а сиромашнији су заједнички куповали вино и њиме се частили. Наиме, одвојено су се веселили богати и сиромашни; богати су се скупљали око игумана, попа и бележника." (Филиповић, 1958: 294-295).

${ }^{12}$ Статистички подаци у: Степанов/Степанов, 2014.

${ }^{13}$ „Наиме, према предању, пре, отприлике, двеста година, у овом пољадијском селу догодио се незапамћен помор деце (више од 60 малишана умрло је само у једној годину). И као да, само по себи, одумирање потомства једног села није довољна страхота, чак ни поље, неколико година заредом, није давало рода. Затечени оваквим стањем ствари, престрављени и беспомоћни, страхујући од потпуног уништења, преци Ланговаца су учинили оно што им је у тим околностима и у том времену једино и преостало. Оно што и данас многи чине кад им је најтеже, кад наука и савремена достигнућа не помажу. Потражили су спас и избављење у молитви. Уз литију, износећи иконе, молећи се заједничким молитвама, предвођени тадашњим свештеником, обишли су село и читав атар у нади да ће им молитва бити услишена. И све су то учинили на источни петак, првог петка после Ускрса. Заједнички молебан, услед поменутих недаћа, донео је, каже предање, очекивану помоћ. Престао је помор најмлађих, а поље је вредне мештане даровало опет својим плодовима.” (Деспотовић, 2017: 28-29).
} 
Данас је сећање на време у коме је крст подигнут избледело (идемо, то је, не знам од колико година; Не знам да Вам кажем то, не знам шта да лажем, не знам да Вам кажем, то ко зна колико године има од ондак од кад је то било). Традиција се преносила усменим путем (Ја знам за девојке, то су причали да за девојке, да.), и конкретан разлог за прихватање и поштовање празника и данас је у Ланговету свима познат (јел умирала дещза овдена; код нас умирале девојке; умирала су деща; младеж умире). Сам крст је током времена обновљен и пренет на погодније место, даље од државне границе (један тео да прави за његово дете, и он прао крст ту, ту; било опет тамо чак код гарнице доле тај крс, и сад га премештили).

У насељу постоји свест о томе да је њихов обичај јединствен (ми смо славили, друга села не славу, само ми; а то само наме село слави) и да је значајан за целу српску заједницу у Румунији (Били, мислим да из Темишвара, Српског савеза били туна). Сви саговорници о празнику говоре са поносом, посебно указујући на активно учешће школске деце (Jaо, па било лепо, деца праила програм, у школа, јако организовали лепо; овај петак ту било пуно света ту у школу праили програм, играла деца и пуно из иркве, кад је готова литија, опет иде литија око села, иде тамо и кад се врату онак дођеду у, тунак у то двориште, у школу и ту праила деца програм и играли и певали, смо седели, смо ту гледали).

[1] Када сиђете на лево, ту, ту су правили сад, ту се долази јел умирала деца овдена у Ланг-, у Луговет, ми кажемо Ланговет, и славили први петак посе Ускрса, тај петак од како славиду тај петак деца нису више умирала. И ту фурт су изилазили и ондак један тео да прави за његово дете, и он прао крст ту, ту. А сад смо ишли, ми смо казали има један кладанац Видара се зове, то смо ишли други дан на Дова, на тај кладанац и ту био један крс. [...] (БС: Значи иде различито литија?) Да, да. На сваки светак, тамо на Дове, овде на петак после Ускрса, петак после Ускрса, тако се иде. Јао, па било лепо, деца праила програм, у школа, јако организовали лепо. Били, мислим да из Темишвара, Српског савеза били туна.

[2] Јао, да Вам кажем, код нас умирале девојке. Иде летија на Дове и посе Ускрса, један петак тај славимо највише, то иде летија, изван села имамо крс напоље, знате. И на Дове плетемо венце, иду младе, плетеду венце и онда иде летија. (Ch: Ајде сад кажите ми за, за тај петак после Ускрса то што су умирале девојке.) Умирале девојке код нас. И ондак смо. (СЋ: Од чега умирале девојке?) Младе, тако се умирало, бола дође, умире. И ондак тако, не знам, црква решила тај петак да славимо и ми смо славили, друга села не славу, само ми. Али идемо летија и славимо сила тај петак, ома посе Ускрса први петак. (Ch: Јел то, одакле крене летија тад?) Из цркве. (Ch: Из цркве?) Из цркве, идемо око села, имамо прављено и овамо, ка Златици, а имамо и ка Сакаловцу крстове прављене, идемо да се молимо Бога, клечимо и литија иде и изиђу жене сокаком, фрљамо жито, намештимо сито, да, фрљамо жито. Шта оћете још? (Cћ: Јел престале да умиру девојке?) Да, од онда престале, не 
умирају девојке више. Да, тако је било, младеж умире онда и то су решили и тако да је. Смо, идемо, то је, не знам од колико година. (CЋ: А јел се посушило жито и виногради тада када су и те девојке умирале, или?) Не знам да Вам кажем то, не знам шта да лажем, не знам да Вам кажем. Ја знам за девојке, то су причали да за девојке, да.

[3] Има код нас петак тај, то после Ускрса то, и онда, кажу, умирала су деца, а то само наше село слави, и то се иде тамо, било опет тамо чак код гарнице доле тај крс, и сад га премештили чак, па сте прошли кад сте дошли од Златице, одонуд. (СЂ: Јесте, јесте, бели један као?) Бели, да, тако тај велик, то. Ту су праили тунака сад тај крс. [...] (СЪ А како је тај други што сте запричали?) На ту децу? (Съ: Дабоме.) И онак то ишла литија тамо на тај крс за децу, то се молу и сад су опет, овај петак ту било пуно света ту у школу праили програм, играла деца и пуно из цркве, кад је готова литија, опет иде литија око села, иде тамо и кад се врату онак дођеду у, тунак у то двориште, у школу и ту праила деца програм и играли и певали, смо седели, смо ту гледали. (CЂ: А јел то скоро подигнуто, тај крст ил није?) Па тај је крс скоро подигнут, а доле тамо је тај од старине, још одавно, то ко зна колико године има од ондак од кад је то било. (СЂ: Тај исто је био за ту децу?) Да, за ту, за ту децу и као, ја знам за то, да. (СЂ: Значи, раније био један крст за децу?) Да, тамо доле, и после га тога премешћали, сад више не знам, дал преместили, ваљда покварили па пренели овде, бацили су, праили нов крс. [...] Овај је био тамо горе ка Видари како ми кажемо, овај био тамо доле Садове се звало то ди је био. (СЪ: А е се причало како подигнут тај крст за ту децу? Ко то организово?) Па село је то. Не знам ко је то организово, како је то пре било, и. И тако да.

Саговорник (пример [1] ) се разликује од других интервјуисаних саговорница својом метапрагматичком свешћу (што ће се показати и у неким од следећих примера), овде користи коментар и аутокорекцију локалног ојконима $^{14}$ за који претпоставља да може бити непознат истраживачу из Србије (умирала деца овдена у Ланг-, у Луговет, ми кажемо Ланговет). На молбу истраживача да се не труди да мења свој говор током снимања интервуја, исти саговорник, а за разлику од многих других Срба у Румунији - а пре свега оних у Арадској жупанији и Банатској Црној Гори - уверен је да говори исправно: (БС: Нама треба да говорите као овде што се говори, у, у селу. Значи, не као, да говорите као у граду.) Прао српски говоримо. На овакав позитиван став о својој језичкој компетенцији утицала је сигурно и непосредна близина границе, чести контакти са људима из Србије и праћење медија на српском језику, пре свега телевизијског програма. ${ }^{15}$

\footnotetext{
${ }^{14}$ Типологију аутокорекција у говорном језику в. у: Цесарская, 2015.

15 За разлику од савременог саговорника, почетком двадесетог века историчар Дејан Адам сматра да он као и други Срби у Пољадији говоре искварено: „Читање народних песама помогло ми је да добро научим наш књижевни језик, јер су овдашње Банатске Ере доста искварено говорили српским језиком, са много германизама и провинцијализама па сам и ја говорио као и они” (Адам, 1992: 97-98).
} 


\section{2. Савремена историја: 1947.}

За илустровање сећања на време постављања границе 1947. учинила се погодном једна добро позната и у хуманистичким наукама веома дискутована теорија француског социолога Мориса Алвакса (Halbwachs, 1950). Наиме, Алвакс указује на могућност да се различите фазе нашег живота тек накнадно могу повезати са догађајима од националног значаја, а када је реч о историји доживљеној у детињству - потребно је да протекне извесно време да би се схватио смисао неког догађаја и његово историјско значење. Тек на основу понашања одраслих дете сазнаје да је неки догађај заслужио да се запамти. Што се тиче сећања на далеке претке, најближи сродници се умећу између нас и њих, о њима и дешавањима из њихових живота знамо само оно што су нам старији саопштили, прошлост се посматра са њихове тачке гледања.

Управо овако, са елементима накнадног промишљања, у својим сећањима на детињство проведено у пољадијском селу Златица, историчар Дејан Адам (1904-1980) описује одлазак свог оца у рат 1914. из перспективе десетогодишњег детета: „Када данас, после шездесет година, размишљам о оним догађајима, сећам их се многих до детаља, али и да онда нисам ништа схватао шта све то значи. Зашто толика жалост и толики плач? [...] Све је то на мене јако утицало и схватио сам да се ипак нешто страшно у породици догодило, али шта - то нисам разумевао.” (Адам, 1992: 69).

У наставку следе екстензивни одломци из наратива на тему усмене историје о затварању границе која помињу Белу Цркву као важан градски центар коме још увек те 1947. године гравитирају становници Пољадије: тамо се свакодневно носи роба на пијацу, иде у куповину (мој отац ондак отишо у Бела Цркву [...] из тога левога цепа извади ми ту таблу малу) или код лекара за хитне потребе (То пантим, и сад ми остало слика, лекар, то. (БС: А то у Бела Цркву?) Да, у Бела Цркву. Па, нисмо ишли, ди д идеш даље).

Свет детета у Пољадији, као што је то било свуда у руралним заједницама средином 20. века, био је ограничен породицом (до четерес седме године, моја бака покојна, она иде ујутру на пијаще) и школом (имала сам учитеља Бранка из Југославије, ја сам у школу. Четерес седме се затворила). ${ }^{16}$

Година коју саговорници тачно памте и спонтано помињу у наративима јесте управо та 1947 (то било четерс седме године, четири године, сам био мали), док су за све друге - из угла истраживача историјски важније године - многи саговорници изражавали одређену несигурност чак и када су били директно питани (Резолуција Информбироа, депортација у Бараган, присилна колективизација земље, односно - време увођења задруга).

\footnotetext{
${ }_{16}$ Дечију перспективу у сећањима на неке обичаје из домена традицијске културе Срба у Румунији в. у Сикимић, 2016, 2018.
} 
[4] па Бела Црква нам најближе нам. Ми имамо само од наше до пијаца до Беле Цркве од крај села имамо један километар и по. Прескочимо Неру и омак смо у Белу Цркву на пијаце. ${ }^{17}$ На. Па док је, до четерес седме године, моја бака покојна, она иде ујутру на пијаце и после дође кући, ради. Носила, тамо биле Швабе много, знате, носиле млека, сира, јаја, то све тамо.

[5] Тако било онак. А до четерес седме ми смо ишли туде, нисмо ишли нигде, да. Ја пантим, сам био мали, сам пао, сам разбио главу и ме водила мајка код лекара. И сад ми остала слика како сам га видо, лекар, бео мантил, наочаре као ја на очи и отишо сам тамо, дете. А шта сам имао, то било четерс седме године, четири године, сам био мали. То пантим, и сад ми остало слика, лекар, то. (БС: А то у Бела Цркву?) Да, у Бела Цркву. Па, нисмо ишли, ди д идеш даље, шта д идеш, а ишли у Молдаву само носили рану.

[6] И сад, ова деца била већ старија, ја сам четрес прве била и четрдесете године, после подне ће пођу у школу, време за школу. А ја шта знам, идем ја с њима, као сигра, бре тако како смо се играли, идем с њима. Данас, сутра, прекосутра и онак био учитељ Бранко из Југославије. ${ }^{18}$ И он видо мојга оца, на ћошку тамо и каже: „Брате, молим те,” каже, „девојка долази,” каже, „сваки дан,” каже, „у школу, а нема, нема.” Није толико, два, три дана, колко ј било. „А нема на шта,” каже, „да пише.” Каже: „Па моја девојка не иде у школу.” Каже: „Како да не иде,” каже, ,дође сваки дан.” Дође кући, пита. „Па јесте.” А моји ни не знаду да ме преобучеду, да ме, што се каже, да се спремим за школу, да идем. Јао. Добро. Ондак, имале смо једном, моа мати имала неку сестрицу њену, па њена девојка, па је била до краја учитељка, опет. И пошље њене табле, ако знате како су биле табле, тако, и пошље једну таблу, тако била овако пукнута. Узела сам то и онак, памтим, то сам ишла у школу да то пишем, с једне стране коцке с једне стране има оно мале линије и велике. Кад тамо, мој отац ондак отишо у Бела Цркву и пантим како нам у собу ушао тако, овако било врата ко ова, и кад ушо, тако, тако нам био астал, ушо и како биле чакшире пре, ${ }^{19}$ знате, тако, из тога левога џепа извади ми ту таблу малу, тако, да ми таблу, још ми код мене та табла. Извади ми ту таблу, то ми дао, ондак ми везали на то, кум кад ме крстио од свиле плаве, бело и плаво, тако ситно имало по њојзи, била моја баба та, она сама опет шила

\footnotetext{
${ }^{17}$ У својим сећањима на детињство проведено у Златици и Дејан Адам помиње како је његова баба уторком, суботом и понекад недељом носила воће на белоцркванску пијацу, али је о његовом случају вероватно реч о животу у Аустроугарској, односно о времену пре Првог светског рата (Адам, 1992: 41).

${ }^{18}$ У време о коме говори саговорница, школа у Соколовцу била је седмогодишња и већ је била подржављена (српске вероисповедне школе у Румунији биле су подржављене априла 1946). Школске године 1947/48. учитељ у школи у Соколовцу био је Бранко Ковачевић, а у првом разреду 1946-1948. била су 42 ученика (Сабљић, 1996: 48, 222, 231).

19 Чакшире које помиње саговорница вероватно су брич-панталоне од сукна или штофа, до колена уске уз ногу и са широким горњим делом који се сужава око појаса, црне или неке друге тамне боје какве су се у Пољадији носиле после Првог светског рата, уп. Крстић, 2015: 328. Етнографски опис херских чакшира в. у Лунгин Максимовић, 1958: 201-202.
} 
и она то парче то свиле ${ }^{20}$ ми везала на ту таблу и тако сам ишла, тим да пишем тамо, у школу. И памтим и то, баш комшија што ми био одма на десну страну, он је био триес девете рођен, млого старији, а био неки израсан, онако висок. Кад дође ту један, како у Сакаловац је школа та била, сад није ту, сад школа је прављена велика, одма на леву страну је била та наша српска, а у десну страну била је румунска школа. И дође тај румунски учитељ и каже: „Што држиш,” каже, виш ко мене, „ову девојку,” каже, „кад она?” нисам, нисам за школу. Нисам имала ни шес година. Ја сам у септембар пошла, а октобар сам напунила шес година. Деца раније ко саде што од детињства на интернете, на телевизор, на свашта, ми то све нисмо знали. Кад тамо, онај ондак шта ће, изведе мене, изведе тога комшију. А како да Вам кажем, млого тако, мене све ми остало оно пред очи, тако уђе на врата и ондак ту је била ома табла и ондак тог учитеља нашег астал, и тамо била фуруна као у крај. И он изведе и мене и тога комшију на таблу. У ондак тера њега тамо да напише, кад он пише, не пише како треба. Тера мене, ја напишем како треба. Опет тако и ондак он каже тим, учитељ каже: „Зашто да је пуштимо,” каже, „кући?” А било је, скамије велике, седам деца седела у скамију, само два реда, како да кажем, ту путања, и тамо скамије и овако скамије, знате, ти велики, само. Он ти тако у другу, у другу скамију, ома друга тако сам, ја нисам била с краја него ома тако друга сам била поред. Памтим како сам седела. И ништа. И тако ме остаи и тако сам остала, цело време сам била најмлађа у разред.

[7] (CЂ: Кад се пуштила граница?) Кад се пуштила? Па баш ни не знам како да Вам. (СЂ: Отприлике?) Па четерес седме се затворила. Једном, имала сам учитеља Бранка из Југославије, ја сам у школу. Четерес седме се затворила, а четерес девете смо ушли у колектив и после, у Сакаловац. Тамо у Сакаловац, Белобрешка пре су ушли у колектив.

Могуће је да саговорница добро памти 1947. годину јер се поклопила са важним датумом у њеној личној биографији, односно годином њеног необичног, прераног поласка у школу са непуних шест година. Ипак, историјски значај те исте 1947. године могла је тек накнадно да разуме као историјски важну временску границу, тешко да је као ђак првак могла разумети зашто је њен вољени учитељ (Бранко из Југославије) морао управо тада да напусти школу у Соколовцу.

\section{3. Језички трагови социјализма}

Саговорници из Ланговета не знају да ли неко од истраживача говори румунски, што се иначе на терену ретко постављало као питање истражи-

\footnotetext{
${ }^{20}$ Није јасно о каквој тканини је реч, будући да се у пољадијским селима свећа за крштење обавија белим платном (критеница), а посебно су свила и штоф намењени мајци детета. О свећу је окачена лента - плаве боје за мушко и црвене боје за женско дете, уп. Крстић, 2015: 200.
} 
вачима. Осим једног саговорника (в. примере $[1,4,5])$, у Ланговету се недоследно показује метапрагматична свест да неки термини и реалије могу бити непознати људима који долазе из Србије. ${ }^{21}$ У контексту разговора на теме усмене историје, питању су пре свега били термини везани за специфичности румунског социјализма (за употребу ових термина у Банатској Црној Гори уп. Сикимић, 2019). Ипак је једна саговорница румунски термин chiabur (иначе турцизам) у следећем примеру одмах превела приближним али идеолошки необојеним: богаташ. Идеолошки корелат четрдесетих година двадесетог века у социјалистичкој Југославији био би русизам кулак, који је иначе коришћен и у румунској идеолошкој пропаганди тога доба:

(Ch: А што су их терали у Бараган?) Па не знам да Вам кажем зашто. Па ко рачунали да су кјебури, богаташи, а нису били не знам како богаташи, него терали и тако. Шта да Вам кажем. И шта да Вам кажем, било је и зло и добро, трпели смо, ћутали смо, провели смо млого, не?

Истраживачи активно користе румунски термин колектив за једну од најважнијих тема за истраживање усмене историје села у периоду социјализма у Румунији - рад у задругама. Саговорник из Ланговета у дијалогу не прихвата аутоматски истраживачев рутински употребљен термин колектив већ користи одговарајуће српске термине, и то тачне еквиваленте: задруга и земзадруга уз метапрагматично објашњење: колектив, тако се звало. Саговорнице, међутим, не осећају потребу да истраживачу протумаче било који од термина везаних за рад и радне односе у време социјализма:

(БС: Је л то за време Чаушескуа била овде колектив?) Да, да, била да. (БС: И земљу су Вам узели?) Па радили смо у задругу, нас платили, сви ко је радио, била задруга као. Тако је било ондак време до, до деведесет и осме, девете године. (БС: Осамдесет девете.) Осамдес девете, онда да, пропале задруге, ете то смо. [...] Ниси мого, већ је радила земзадруга, колектив, тако се звало, то је била земзадруга, су радили људи и ту су сејали кромпире, сејали све и парадајзе и све, све се и онак они носили у град, носили су у град, носили у град да продаједу

Смо морали да уиђемо сви у колектив онда. Обавезно. И онда смо све дали, и марву, кола, трактор, шта си имао. Све смо дали у колектив.

Има, то се звало продукције, нам поделу, врсте, свима једнако, женама, била је екипа, био шеф екипе и онда нам, кукуруз.

\footnotetext{
${ }^{21}$ Чињеница је да у основном језичком фонду Пољадијаца има веома мало румунизама, што глагол парасити 'напустити' употребљен у следећем примеру свакако јесте:

зидали мајстори, све то је она платила, све то било, било све парашено, не рађено ништа, нико толики година кад је граница затворена. Она све га средила изнова.

али је ова лексичка позајмљеница потврђена и у српском делу Баната, уп. пример из Зрењанина забележен средином двадесетог века: Мој отац је парасио (као кад човек, изостави свој занат), парасио се чобанлука, три године није чуо овце (Секулић, 1981: 149).
} 
Пре је била наша земља смо радили, било теже, давале се коте, ${ }^{22}$ поричје.

тамо у Румунију унутра су страдали, нису имали леба, нису имали. Давали на картеле полак леба, фртаљ леба ти да, е а ми овде смо имали, смо живели добро.

Специфичан геополитички положај насеља на граници, осим вештачке раздвојености од сународника са друге стране реке, током периода социјализма (али тек после обнове односа две државе) постаје и својеврсна привилегија. Становници Пољадије имају прилике да развију и посебну 'пограничну' лексику, о чему духовито пише један чланак у темишварској „Нашој речи”:

Као деца границе, Клисурци и Пољадијци који су вековали на размеђи империја и краљевина, врло су подозриви при помену термина попут „царина”, „граница”, „пасош”, „вамеш”, „пашапорт”... У свакодневном животу близина „фашије” подразумева нимало пријатне контроле, забране, сумњу. Посматрано из другог угла, могло би се рећи и да је бодљикава жица појединцима више пристајала као позамашна, златна огрлица око широких вратова, него као студен ланац око заврнуте шије. Ако су се у време прошлог режима на списку робне размене (или како то неки зову - шверц), налазиле дуксер гаће, со, производи од макрамеа, Вегета, Ципирипи, Викенд, касније нафта, а када је ембарго дошао до издисаја, све и свашта, у последње време тај списак је готово празан. (Деспотовић, 2010: 18).

Називи за документа неопходна у малограничном промету користе се наизменично и слободно у румунској и у српској верзији: пасош (али нико од саговорника ипак није употребио румунско paşaport), лична карта се користи уз еквивалент булетин (рум. buletin), дозвола уз пермис (рум. permis), цзарина уз вама (рум. vamă). Уз граница користи се и дијалектска форма: гарница (румунски језик за овај појам користи славизам graniță па саговорници из Пољадије не користе дублетне форме; у службеној употреби румунски језик користи и синонимни неологизам frontieră). Овај специфични 'погранични' билингвизам сведочи о заиста честим (легалним) преласцима границе који су у овом правном облику постојали довољно дуго и успели да успоставе минималан, али стабилан двојезични систем са неколико службених термина. ${ }^{23}$ Саговорници на терену Румуније, чак и када говоре

\footnotetext{
${ }^{22}$ Раул Јонуц Рус (Raul Ionuț Rus) указује да је пољопривредни откуп у социјалистичкој Румунији прошао кроз четири периода: 1945-1947 (систем квота); 1948-1952 (период правне нестабилности); 1953-1956 (систем уговора - контраката) и 1957-1962 (период контраката уз насилну колективизацију после 1958). Детаље о обавезним пољопривредним квотама (рум. cotă) у периоду 1945-1948 в. у: Rus, 2012.

${ }^{23}$ Румунске позајмљенице овог типа Жива Милин категоризује као 'акти и документи': адевериниа 'уверење', булетин 'лична карта', ливрет 'војна књижица', ћертификат 'сведочанство', ћитащија 'позивница на суд' (Милин, 2013: 121). Термини везани за границу и прелазак преко границе нису наведени у његовој студији, можда зато што становници
} 
о садашњем времену, често у разговору наводе стари назив суседне државе (Југославија), званични назив државе са друге стране границе, промењен 2006. године у Републике Србија, и даље није спонтано прихваћен.

Јел ми нисмо бегали, ми нама нам дали пасоше, ми смо могли д идемо с пасошем, нико ме не гледа и шта је

Кад је било то, у Кусић тај, шта је било то, грожђен балови шта су били, онак туда идемо тамо и туда се вратимо с булетинима, нису још ни били пасоши испочетка. А после доцније, кад смо добили пасоше, онда смо ишли. Онда смо ишли тамо лепо на ваму.

(СЪ: А пре тога? Кад био колектив?) Кад је био колектив смо ишли кад ондак на пасоше, смо имали дозволе, смо имали дозволе, сад се иде на личну карту, а пре смо имали пасоше, смо праили. Па да. Па имали смо пасоше, нисмо могли д идемо тако.

Смо добивали рану, мало паре, и посе ми ова околина око Југославије смо имали пермисе, нисмо имали велике пасоше, даље четрдесет километара даље од границе они нису могли да дођу, нико, Румуни да иду у Југославију, само ми, околина, те комшије, смо ишли. И смо имали пасоше мале, дванајс пут смо имали на тај пасош да идемо годишње, и онда смо ишли.

све што год је било, све из Југославије смо донесивали, смо шверцовали, смо, идемо, имали смо пасоше, на ваму прођемо, ујутру идемо, увече дођемо или седимо по два три дана, имали смо прао шес дана да седимо на тај мали пасои.

На светац су прелазили, није то било готово, да. И сад било говор и у Сакаловац, ту је било опет пре, граница била, вама, царина, а видим не отвараду.

Била сам дете, ал некад ја памтим. И ми смо тамо седели, како да кажем, уз, код нас је било у гардину, како биле фашије пре, знате, уз гарнииу. А и тамо било ниже

Последњи пример садржи термин фашија (рум. fâşie), који сведочи о постојању још једне 'пограничне' реалије из доба социјализма: по затварању границе у периоду Информбироа постојали су посебни заштитни појаси земље уз границу (како биле фашије пре) и посебна војна контрола унутар насеља која се, уз илегалне преласке границе, у наративима само узгред помињала. Могуће је да и данас тема 'илегалне' границе код старијих саговорника активира аларм 'забрањене' теме и аутоцензуре.

Банатске Црне Горе у периоду социјализма нису били обухваћени малограничним прометом и, као и други становници Румуније, тешко су добијали пасоше. 


\section{Завршна разматрања}

Сложена тема живота у пограничју у овом прилогу сведена је практично само на један сегмент: сећање на 1947. годину, годину успостављања границе која радикално мења свакодневни живот у Пољадији. Некадашњи центар регије Банатских Хера, Бела Црква, тек после пада комунистичких режима постепено враћа свој статус важног трговачког центра и за херска насеља са румунске стране. Систематски тимски истраживачки рад на документовању језика и културе Срба у Румунији, реализован захваљујући иницијативи Савеза Срба из Румуније, показао је да, после пуних сто година раздвојена границом, и херска насеља са друге стране Нере/Нераља заслужују једнако озбиљна и систематска истраживања. ${ }^{24}$

\section{Литература}

Адам, 1992: Д. Адам, Сећање на детињство у селу Златищи, Београд: Етнографски институт САНУ.

Бошњаковић, 2019: Ж. Бошњаковић, Колико је државна граница утицала на прозодијски систем говора М. Гаја (у Румунији) и В. Гаја (у Србији), Исходишта 5, 69-82.

Букуров, Филиповић 1958: Б. Букуров, М. Филиповић, Херска села у Румунији, Банатске Хере (М. Филиповић, ур.), Нови Сад: Војвођански музеј, 51-53.

Деспотовић, 2017: П. Деспотовић, Подсећање, молитвено и свечано у Луговету, Нама реч 1418, 28. 4. 2017, 28-29.

Деспотовић, 2019: П. Деспотовић, Свети Илија у Лесковици, Наша реч 1537/1538, 9. 8. 2019.

Деспотовић, 2020: П. Деспотовић, Цариник, слава и роловано прасе, Нама реч 1564, 21. 2. 2020, 18.

Ивић, 1958: П. Ивић, Место банатског херског говора међу српским дијалектима, Банатске Хере (М. Филиповић, ур.), Нови Сад: Војвођански музеј, 326-353.

Илић, 2006: С. Илић, Народне мелодије Срба, Шокаща и Карашеваща у Румунији (Ј. Јовановић, прир.), Београд: МИ САНУ и Матица српска.

Крстић, 2015: Б. Крстић, Народни живот и обичаји Клисураща и Пољадијаца, Темишвар: Савез Срба у Румунији.

Лунгин Максимовић, 1958: Б. Лунгин Максимовић, Банатске Хере (М. Филиповић, ур.), Нови Сад: Војвођански музеј,196-210.

Лупуловић, 2003: В. Лупуловић, Развој школства у Луговету, Темишвар: Савез Срба у Румунији.

\footnotetext{
${ }^{24}$ У овом смислу одличан подстицај дао је дијалектолог Жарко Бошњаковић својим радом у два насеља раздвојена државном границом (Мали и Велики Гај), уп. Бошњаковић 2019.
} 
Лупуловић, 2012: В. Лупуловић, Српска православна парохија из Лесковице кроз време, Темишвар: Савез Срба у Румунији.

Лупуловић, Гароју, 2008: В. Лупуловић, А. Гароју, У име Божје: прича о оснивағу пољадијских манастира, Темишвар: Савез Срба у Румунији.

Лупуловић, Крстић, 1999: В. Лупуловић, Б. Ђ. Крстић, Соколоваи (Монографија), Темишвар: Савез Срба у Румунији.

Лупуловић, Крстић, 2001: В. Лупуловић, Б. Ђ. Крстић, Осмогодишња школа у Соколовцу, Темишвар: Савез Срба у Румунији.

Лупуловић, Томашевић, 2007: В. Лупуловић, В. Томашевић, Храм Светог пророка Јеремије у Луговету, Београд: В. Томашевић.

Милин, 2013: Ж. Милин, Стране речи у говору банатских „Црногораца”: немачке, мађарске, румунске, Српско језичко наслеђе на мултикултурном простору Баната (М. Радан, прир.), Темишвар: Савез Срба у Румунији, 113-126.

Милин, Милин, 2004: М. Милин, А. Милин, Срби из Румуније и румунско-југословенски односи, Вршац: Виша школа за образовање васпитача.

Милин, Милин, 2009: А. Милин, М. Милин, ССКДУР или Срби из Румуније на барикадама хладног рата, Темишвар: Савез Срба у Румунији.

Милин, Милин, Михајлов, 2011: А. Милин, М. Милин, Ц. Михајлов, Срби у Румунији за време комунизма, Темишвар: Савез Срба у Румунији.

Сабљић, 1996: Д. Сабљић, Српско школство у Румунији 1919-1989, Темишвар: Демократски савез Срба и Карашована у Румунији.

Секулић, 1981: Н. Секулић, Збирка дијалекатских текстова из Војводине, Српски дијалектолошки зборник XXVII, 107-306.

Сикимић, 2016: Б. Сикимић, Обредна јела у Војводини и Поморишју приликом клања свиња. Савремена теренска истраживања, Slavische Geisteskultur: Ethnolinguistische und philologische Forschungen. Teil 1, (Alekseev, A. etc. Hrsg.), Philologica slavica vindobonensia 2: Frankfurt am Main [u.a.], 157-180.

Сикимић, 2018: Б. Сикимић, Теренска истраживања Срба у Клисури: обичај кумачење, Исходишта 4, Темишвар 2018, 309-322.

Сикимић, 2019: Б. Сикимић, Станчево: наративи о раду и сиромаштву, Исходишта 5, Темишвар - Ниш, 403-424.

Станојловић, 1938: А. Станојловић, Монографија Банатске клисуре, Петровград: Гутенберг.

Филиповић, 1958: М. Филиповић, Слава или светац, Банатске Хере (М. Филиповић, ур.), Нови Сад: Војвођански музеј, 292-295.

Филиповић, 1958а: М. Филиповић, Постанак и развитак групе Банатских Хера, Банатске Хере (М. Филиповић, ур.), Нови Сад: Војвођански музеј, 355-397.

Филиповић, 1958б: М. Филиповић, Ко су Банатске Хере, Банатске Хере (М. Филиповић, ур.), Нови Сад: Војвођански музеј, 13-14.

Цветковић, 2011: В. Цветковић, Црвена Армија на Дунаву, у: ССКДУР или Срби из Румуније на барикадама хладног рата (А. Милин, М. Милин, Ц. Михајлов, ур.), Темишвар: Савез Срба у Румунији, 310-318. 
Цесарская, 2015: А. Е. Цесарская, Автокоррекция как стратегия реализации программы взаимодействия говорящего и слущающего, Вестник Томского государственного университета 398, 21-29.

Cvetković, 2013: V. Cvetković, Pogled iza gvozdene zavese. Jugoslovenska politika premazemljama narodne demokratije u susedstvu 1953-1958, Beograd: Institut za noviju istoriju Srbije.

Đurić-Milovanović, 2007: The cross with four pillars as the center of religious gathering: discussing micro regional identity, Ethnologia Balkanica 11, 171-184.

Halbwachs, 1950: M. Halbwachs, La mémoire collective, Paris: Presses Universitaires de France.

Milin, Milin, 2014: Clisura bănățeană (a Dunării) - enclavă iugoslavă nord-dunăreană în anii 1944-1947 sau experiment comunist românesc ,avant la lettre”, Analele Banatului, s.n. Arheologie - istorie XXII, 445-473.

Milin, Milin, 2017: M. Milin, A. Milin, Sârbii din România, documentar şi studii despre remodelarea identitară, Târgoviște: Editura Cetatea de Scaun.

Radan, 2003: M. Radan, Lescovița. Intre trecut și prezent. Monografie, Timișoara: Editura Mirton.

Rămneanțu 2004-2005: V. Rămneanțu, Câteva considerații privind starea de spirit a locuitorilor din județul Timiș-Torontal în anul 1947, Analele Banatului, s.n. Arheologie - Istorie XII-XIII, 481-507.

Rus, 2012: R. I. Rus, Cotele obligatorii și țărănimea în județul Timiș - Torontal 19451948, Analele Banatului, s.n. Arheologie - Istorie XX, 393-400.

Biljana Lj. Sikimić

\title{
POLJADIJA REGION IN ROMANIA: LIVING ON BORDER LINE
}

\begin{abstract}
Summary
The paper is based on the data collected by team field research of the Serbs in the settlements Sokolovac (rom. Socol), Zlatica (rom. Zlatiţa) and Langovet (rom. Câmpia) conducted at the beginning of June 2019, organized by the Center for Scientific Research of Serbs in Romania, of the Union of Serbs in Romania. These three settlements are situated at the left bank of the river Nera that become YugoslavRomanian state border in 1919, the same state border being again officially confirmed by the Paris peace treaty 1947. The border line villages in Romania were separated from their land properties at the right side of the river, and, at the same time, from the prior regional city center of Bela Crkva that remained in Yugoslavia. Focusing only four transcriptions of all the interviews held in Langovet, this paper sheds light on closing state border time in 1947 from the children's perspective. Collective memory still retains reasons for the local celebration of the first Friday
\end{abstract}


after Easter, remembered as deadly disease of children or young girls'. This local holiday currently became one of the important ethic symbols in the official calendar of Serbs in Romania. Metapragmatic awareness of good knowledge of native Serbian language is discussed at the level of socialist period vocabulary and Romanian administrative lexicon covering border line and border crossing conditions ('passport', 'frontier', 'customs'.)

Key words: border studies, oral history, personal biography, Serbs in Romania, socialism, Câmpia. 